\title{
Feature of Experimental Breast Cancer Induced by Intermammary Administration of N-Methyl-N-Nitrosourea in Wistar Rat
}

\author{
Alexander P. Lykov ${ }^{1,2, a^{*}}$, Alexei V. Kabakov ${ }^{1, b}$, Oleg V. Kazakov ${ }^{1, c}$, \\ Natalia A. Bondarenko, ${ }^{1,2,}$, Olga V. Poveshchenko, ${ }^{1,2, e}$, Tatyana V. Rayter ${ }^{1, f}$, \\ Alexander F. Poveshchenko ${ }^{1,2, g}$, Dmitri N. Strunkin ${ }^{3, h}$, Sergei S. Bogashev ${ }^{4, \text { i, }}$, \\ Eugenii A. Pokushalov ${ }^{5, \mathrm{j}}$ and Vladimir I. Konenkov ${ }^{1, \mathrm{k}}$ \\ ${ }^{1}$ Scientific Institute of Clinical and Experimental Lymphology, 2 Timakova Str., \\ Novosibirsk, 630090, Russia; \\ ${ }^{2}$ Novosibirsk Scientific Institute of Circulation Pathology, 15 Reshkunovskaya Str., \\ Novosibirsk, 630055, Russia \\ ${ }^{3}$ Scientific Institute of Fundamental and Clinical Immunology, 14 Yadrintsevskaya Str., \\ Novosibirsk, 630099, Russia \\ ${ }^{4}$ Institute of Cytology and Genetics, 10 Lavrentieva Ave., Novosibirsk, 630090, Russia \\ ${ }^{5}$ Novosibirsk Scientific Institute of Circulation Pathology, 15 Reshkunovskaya Str., \\ Novosibirsk, 630055, Russia
}

aaplykov2@mail.ru, bdoctor03-85@ngs.ru, 'kazakoff@mail.ru, dbond80288@yandex.ru, epoveshchenkoov@yandex.ru, reitert@mail.ru, ${ }^{\mathrm{g}}$ poveshchenkoa200@mail.ru, ${ }^{\mathrm{h}}$ strunkind@mail.ru, 'gorbi@bionet.nsc.ru, 'e.pokushalov@gmail.ru, kvikonenkov@gmail.ru

Keywords: Breast Cancer, Breast Cancer Cells Phenotype, Chemotherapy, Panagen, Tumorassociated Mesenchymal Stem Cells, Sex Hormones, Cytokines, miRNA.

Abstract. Breast cancer is the leading cause of cancer death in women worldwide due to the complicated etiology involving both genetic and environmental factors. BC was induced by $N$ Methyl- $N$-Nitrosourea administration intermammary in Wistar female. Studied frequency of development of NMU-induced BC, phenotype of BC cells, phenotype of MSC from mammary gland tissue, quantity and quality of immunocompetent cells, expression of miRNAs, hormone levels and cytokines were done for estimate sensitivity to chemotherapy. We showed that MNUinduced $\mathrm{BC}$ developed in $90 \%$, immunohistochemical similar to human luminal A type of BC with higher proliferation activity. We estimated significantly increased count of BC-MSC with CD45+CD90-, and CD45+CD90+, and CD45-CD90+ phenotype in animal with MNU-induced BC. Chemotherapy caused changes in quality and quantity of immunocompetent cells, decrease of prolactin and luteinizing hormone levels, and some changes in expression of pro-oncogenic or tumor-suppressing miRNAs. In MNU-induced BC animal were observed increased serum levels of pro-inflammatory cytokines. In regional lymph nodes found increased count of macrophages and presence of tumor cells. Intermammary administration of NMU possessed to breast cancer development with similarities to human luminal B phenotype. This MNU-induced breast cancer may serve as a model to study efficiency of chemotherapy.

List of abbreviation: Breast Cancer (BC), $N$-methyl- $N$-nitrosourea (MNU), MicroRNA (miRNA), Mesenchymal Stromal/Stem Cells (MSC), Cyclophosphamide, Methotrexate, 5-Fluorouracil (MCF), fragmented exogenous DNA (fDNA), Phosphate-buffered Saline Solution (PBS), Peripheral Blood Mononuclear Cells (PB-MNC), Bone Marrow Mononuclear Cells (BM-MNC), Bone Marrow Mesenchymal Stromal/Stem Cells (BM-MSC), Breast cancer Associated Mesenchymal Stromal Cells (BC-MSC), 3-(4,5-Dimethylthiazol-2-yl)-2, 5-Diphenyltetrazolium Bromide (MTT), nitrite oxide (NO), Interleukin (IL). 


\section{Introduction}

Breast cancer (BC) is the leading cause of cancer death in women worldwide due to the complicated etiology involving both genetic and environmental factors [1]. Therefore, experimental animal models of BC are used for study development and treatment of BC [2-3]. So, experimental $\mathrm{BC}$ model in rat often used for researcher the development of $\mathrm{BC}$ because the main steps of pathogenesis and progression, and also, the histology are similar to $\mathrm{BC}$ in humans [4]. $\mathrm{N}$-Methyl- $\mathrm{N}$ Nitrosourea (MNU) is a DNA alkylating agent which can induce a mammary tumor, and does not require metabolic activation to exert mutagenic effects, and also, the tumors had a more aggressive potential [2-3, 5]. Administration of the chemical carcinogens, dimethylbenzanthracene or methylnitrosourea, to rats results in the development of hormone-dependent mammary adenocarcinomas that are histological similar to human breast cancers [2]. Rat mammary carcinomas display many features of human adenocarcinoma of the breast, such as, histological progression and ovarian hormone dependence [6]. Breast cancer is a hormone dependent malignancy [7-10]. A variety of evidence shows that estrogens play a major role in the etiology of breast cancer [8]. There is now clear evidence that high-normal circulating prolactin levels increase breast cancer risk in both pre and post-menopausal women [7]. Local overexpression of prolactin was found to promote breast cancer development in virgin transgenic animals [7]. Thyroid hormone receptors affect both the normal breast cell differentiation and breast cancer cell proliferation, with effects of thyroid hormones similar to those caused by estrogens [9]. MicroRNAs (miRNAs) are approximately 22-25 nucleotide small non-coding RNAs that bind to the 3'-UTR of target mRNAs and can caused gene silencing via translational repression or target degradation. miRNAs took part in cell proliferation, development, differentiation, tumorigenesis, and are widely dysregulated in various cancers [11]. In addition, in the carcinogenesis of $\mathrm{BC}$ an important role for the cellular composition of the tumor microenvironment, including the stromal cells of the tumor. So, normal stromal fibroblasts of the mammary glands inhibit the growth of tumors, and tumor-associated fibroblasts rather contribute to carcinogenesis [12]. Also mesenchymal stromal/stem cells (MSC) possess angiogenesis in $\mathrm{BC}$ [13-14].

In the present study, levels of circulating in thoracic duct lymph of prolactin, thyroglobulin, and follicle-stimulating hormone, luteinizing hormone, estradiol and the expression levels of miRNA-21, miRNA-221, miRNA-222 and miRNA-429 in breast cancer, induced by MNU intramammary injection in female rat Wistar has been addressed. We show based on the analysis of levels of circulating hormones and miRNAs expression levels in thoracic duct lymph in rat breast cancer model that in thorax duct lymph can detect hormones and miRNAs. Also, we shown that different methods therapy in MNU-induced BC animal caused quantity and quality changes immunocompetent cells. Intermammary administration of MNU possess to development of $\mathrm{BC}$ which can metastasis into regional lymph node.

\section{Materials and Methods}

Animals. Virgin 10-12 week-old Wistar rats, weighted 250-300 g, were obtained from the breeding station of the Institute of Physiology and Fundamental Medicine (Novosibirsk, Russia). The rats were housed in a temperature-controlled room with a 12-h light and 12-h dark schedule. All experiments were conducted in accordance with the guidelines by the Novosibirsk Institute of Clinical and Experimental Lymphology (ICEL). The ethical clearance for using experimental animals was obtained from the ICEL's Animal Ethics Committee. The rats were housed and maintained at the Animal House Unit. Caging and handling of the rats were done in accordance with the good laboratory practice criteria set by the Animal House. The rats were caged in groups of five and fed a standard laboratory diet and water ad libitum. The protocol of anesthesia, breast cancer induction, BC-Resection of breast cancer, post-BC-Resection breast cancer care, chemotherapy, and sacrifice were identical for all animals. Experiments were performed during the light phase of the cycle (10:00-17:00). 
Tumor induction and detection. MNU (Sigma) was administered into second mammary gland on right side to 30 Wistar rats at $30 \mathrm{mg} / \mathrm{kg}$ body weight dissolved in warm physiological saline and acidified to $\mathrm{pH} 5.0$ with acetic acid, once per week 5 times. In control group animal was given an identical volume of physiological saline. 24-weeks after MNU administration, the animals were observed daily and palpated one a week to detect the induction of the tumors.

Tumor treatment. 24-weeks after MNU administration in experimental group of animal the second mammary gland with tumor were excised under anesthesia with a dose of Nembutal $40 \mathrm{mg} / \mathrm{kg}$ body weight intraperitoneally injection (Sigma). Animals from control group and BC-control group don't receive any manipulations, whereas part of $\mathrm{MNU}$-induced $\mathrm{BC}$ animal received chemotherapy alone (CMF group). Among operated animals was randomly divided next groups: Resection group (excised mammary gland with tumor), Resection/CMF group (excised mammary gland with tumor and done chemotherapy), fDNA group (excised mammary gland with tumor and done chemotherapy, and fragmented exogenous DNA). CMF chemotherapy include Cyclophosphamide (Biochimiya, $3 \mathrm{mg} / \mathrm{kg}$ body weight dose intraperitoneally injection once a day during 14 days), Methotrexate (Ebewe, $15 \mathrm{mg} / \mathrm{kg}$ body weight dose intraperitoneally injection on Day 1 and Day 8), 5 -Fluorouracil (Ebewe, $2.5 \mathrm{mg} / \mathrm{kg}$ body weight dose intraperitoneally injection on Day 1 and Day 8). 24 weeks after $\mathrm{BC}$ induction the second mammary gland on right side gland with $\mathrm{BC}$ was cut out

Tissue collection. 24-weeks after administration MNU tumor specimens (thorax mammary glands number 2 on right side) were collected. All tumors and mammary gland tissue on contralateral side were carefully excised, one piece of the gland was fixed in $10 \%$ formalin for histologic or immunohistochemical evaluation and the remaining tissue was frozen and stored at $-280^{\circ} \mathrm{C}$ until further processing. Part of mammary gland was used for RNA isolation and miR analysis. Histopathological examination was performed on 5 - $\mu$ m-thick paraffin sections stained with hematoxylin and eosin (H\&E). Tissue sections were reviewed by two pathologists utilizing a double-headed BX41 microscope (Olympus). Blood samples were taken from aorta ventral is centrifuged at $1500 \mathrm{~g}$ for 10 minutes; serum was collected and stored at $-80^{\circ} \mathrm{C}$ until needed. Thorax duct lymph was collected and stored at $-80^{\circ} \mathrm{C}$ until assayed for hormone, cytokines and miRs. During autopsy, axillaries lymph node, and sternal lymph node, and mesenteric lymph node, spleen, femur was collected.

Immunohistochemistry. Immunohistochemistry to detect the estrogen receptor- $\alpha$, Her $2 /$ neu, progesterone receptor and $\mathrm{Ki}-67$ was performed on 5 - $\mu$ m-thick formalin-fixed paraffin embedded sections cut onto coated slides. The antibodies used were E115 (Rabbit Polyclonal primary antibodies, Novus Biologicals) to identify Estrogen receptor $\alpha$, rabbit polyclonal antigens (Novus Biologicals) to identify Progesterone receptor, SP3 (Rabbit monoclonal antibody, Labvision) to identify Her2/neu receptor, and MIB-5 (mouse antigen, Dako) to identify Ki-67. These primary reagents were followed by a standard streptavidin-biotin-peroxidase 3,39diaminobenzidine immunohistochemical technique.

Spleenocytes proliferation assay in vitro. A spleen was separated from Wistar rat under aseptic condition and kept in phosphate-buffered saline solution (PBS). The organ was crushed and passed through a steel mesh to obtain a homogeneous cell suspension. The spleenocytes were collected and washed twice with PBS after removing the red blood cells through adding $0.83 \% \mathrm{NH} 4 \mathrm{Cl}$ in $0.01 \mathrm{M}$ Tris- $\mathrm{HCl}(\mathrm{pH} 7.2)$. Next, the pelleted cells were resuspended and diluted to $5 \times 10^{6}$ cells $/ \mathrm{mL}$ with RPMI-1640 containing 10\% of FBS (HyClone), and further inoculated into a 96-well plate (100 $\mu \mathrm{L} /$ well $)$, ConA $\left(10 \mu \mathrm{g} / \mathrm{mL}\right.$, Sigma) was added. The plates were then incubated at $37^{\circ} \mathrm{C}$ in humidified incubator with 5\% CO2 for $48 \mathrm{~h}$. All the tests were carried out in triplicate and the cell proliferation was evaluated by 3-(4,5-dimethylthiazol-2-yl)-2, 5-diphenyltetrazolium bromide (MTT) assay. Briefly, $10 \mu \mathrm{L}$ of MTT solution $(5 \mathrm{mg} / \mathrm{mL}$, Sigma) was added to each well and incubated for another $4 \mathrm{~h}$ in dark. The plates were centrifuged to remove the supernatant and then $200 \mu \mathrm{L}$ of DMSO was added into each well to dissolve the MTT-formazan crystals. The plates were shaken for $10 \mathrm{~min}$ to dissolve the crystals. Absorbance of each well was detected spectrophotometrically at $492 \mathrm{~nm}$. 
MNC proliferation assay in vitro. Mononuclear cells were obtained by fractionation in Lymphoprep $^{\mathrm{TM}}$ density solution (density 1.077) from thorax duct lymph. Following centrifugation at $800 \mathrm{~g}$ for $15 \mathrm{~min}$, the cells at the interface were collected and suspended in RPMI-160 media (Gibco) containing 10\% FBS and $80 \mu \mathrm{g} / \mathrm{mL}$ gentamycin, and diluted to $1 \times 10^{6}$ cells $/ \mathrm{mL}$, and further inoculated into a 96-well plate $(100 \mu \mathrm{L} / \mathrm{well})$, ConA $(10 \mu \mathrm{g} / \mathrm{mL}$, Sigma $)$ was added. The plates were then incubated at $37^{\circ} \mathrm{C}$ in humidified incubator with $5 \% \mathrm{CO} 2$ for $48 \mathrm{~h}$. All the tests were carried out in triplicate and the cell proliferation was evaluated by MTT assay.

BM proliferation assay in vitro. Whole bone marrow mononuclear cells (BM-MNC) were flushed from femurs of Wistar rats, and then centrifuged at $800 \mathrm{~g}$ for $15 \mathrm{~min}$, the pelleted cells washed twice with PBS and suspended in DMEM (Gibco) containing 10\% FBS (HyClone) and $80 \mu \mathrm{g} / \mathrm{mL}$ gentamycin, and diluted to $1 \times 10^{6} \mathrm{cells} / \mathrm{mL}$, and further inoculated into a 96-well plate $(100 \mu \mathrm{L} /$ well $)$, ConA $\left(10 \mu \mathrm{g} / \mathrm{mL}\right.$, Sigma) was added. The plates were then incubated at $37^{\circ} \mathrm{C}$ in humidified incubator with $5 \% \mathrm{CO}_{2}$ for $48 \mathrm{~h}$. All the tests were carried out in triplicate and the cell proliferation was evaluated by MTT assay.

Isolation of BM-MSC. Whole bone marrow cells were flushed from femurs of Wistar rats, and then centrifuged at $800 \mathrm{~g}$ for $15 \mathrm{~min}$; the pelleted cells washed twice with PBS and suspended in DMEM (Gibco) containing 10\% FBS (HyClone) and $80 \mu \mathrm{g} / \mathrm{mL}$ gentamycin. Cells were incubated at $37^{\circ} \mathrm{C}$ with $95 \%$ humidity and $5 \% \mathrm{CO} 2$. Forty-eight hours later, the culture medium was changed to remove non-adherent cells. When the adherent BM-MSC culture became confluent, the cells were detached with $0.25 \%$ trypsin, suspended in $1 \mathrm{mM}$ PBS-EDTA and then passaged. These procedures were repeated until the 3 th passage.

Isolation and culture of BC-MSC. Breast cancer tissue was obtained from Wistar rat. Fresh tissue specimens were collected and washed with PBS. The tissue specimens were cut and disaggregated by adding $0.1 \%$ solution of collagenase type I (Sigma). The specimens were subsequently incubated at $37^{\circ} \mathrm{C}$ in humid air with $5 \% \mathrm{CO}_{2}$ during 4 hours. Then was added $50 \mu \mathrm{L}$ of FBS to stopped disaggregation, and cells were washed twice with PBS and suspended in DMEM (Gibco) containing $10 \%$ FBS (HyClone) and $80 \mu \mathrm{g} / \mathrm{mL}$ gentamycin. The medium was replaced every three days after the initial plating. Cells propagated in these conditions had typical fibroblastic phenotype. The cells in passage 3 were used for the evaluation of the experimental results.

BC-MSC phenotype. BC-MCS of passage 3 incubated with monoclonal PE-conjugated antibodies for CD90, with FITC-conjugated antibodies for CD45 (Sony) in the dark for $30 \mathrm{~min}$ at $4{ }^{\circ} \mathrm{C}$. The cells were subsequently washed three times with PBS, resuspended in $500 \mu \mathrm{L}$ FACS buffer $(0.05 \%$ $\mathrm{NaN}_{3}+5 \%$ FCS in PBS) and analyzed on FACSCanto II using FACS Diva (BD).

BC-MSC proliferation assay in vitro. Cells were seeded into 96 -well plates at $10^{5}$ cells/well and $100 \mu \mathrm{M} \mathrm{H}_{2} \mathrm{O}_{2}$ and incubated during 48 hours. The plates were then incubated at $37^{\circ} \mathrm{C}$ in humidified incubator with 5\% CO2 for $48 \mathrm{~h}$. All the tests were carried out in triplicate and the cell proliferation was evaluated by MTT assay.

miRNA assay. Total RNA from breast tumor specimens and thorax lymph was extracted using Qiagen (Rneasy ${ }^{\circledR}$ Lipid Tissue Mini Kit (50), Germany). The isolated RNA was quantified by absorption photometry at 260/280 nm. Optical density of the RNA was between 1.6 and 1.8 . The miR concentration and purity were assessed by NanoDrop ${ }^{\mathrm{TM}} 1000$ spectrophotometry (Nanodrop Techologies, USA) and Aglient Bioanalysyre (Aglient Technologies). Quantitative real-time PCR reaction was performed by Light Cycler 480 system using Light Cycler 480 SYBR Green I Master (Roche). Sequence-specific primers for miRNA-21, miRNA-221, miRNA-222, miRNA-429, and U6 (small RNA) were selected using the primer finder database (www/applied-science.roche.com) and were synthesized by Vector-Best. The gene expression was determined by absolute nucleic acid quantification method with 4.0 Light Cycler software (Roche).

Hormones detection in thorax duct lymph. Lymphatic prolactin, thyroglobulin, folliclestimulating hormone, luteinizing hormone and estradiol concentration was measured by using ELISA kits: GonadotropinELISA-LH, GonadotropinELISA-FSH, ELISA-Prolactin-01, ThyriodELISA-TG (Company Alkor Bio), and Estradiol ELISA (DRG Diagnostic). 
Bio-Plex assay for cytokines levels determination of serum. The levels of 24 cytokines in serum were detected using Bio-Plex Pro Rat Cytokines 24-Plex Assay (Bio-Rad), according to the manufacturers' protocols.

Nitrite Production. Nitrite was measured as an indicator of nitrite oxide (NO) production in supernatants from BC-MSC. NO inhibition assay was conducted using Griess reagent kit for nitrite determination (Molecular Probes). The amount of NO was calculated using a sodium nitrite standard curve.

Statistical analysis. Statistical analysis was performed use Statistica 10.0 (Stat Soft). Data distribution was determined utilizing the Shapiro-Wilk test. The Mann-Whitney $U$ test was used to compare the groups of data that failed to satisfy the assumptions of the parametric test. Correlations between the scores were tested using Spearman's correlation test. Results were considered statistically significant when $\mathrm{p}<0.05$ in all the analyses.

\section{Results}

In the 30 rats, first palpable tumor appeared in the $6^{\text {th }}$ week in four of the rats after MNU administration. In the $12^{\text {th }}$ week of the experiment tumor was palpated in 10 rats $(30 \%)$, whereas in the $18^{\text {th }}$ week and $24^{\text {th }}$ week of the experiment, respectively in $60 \%$ and $90 \%$ of the rat had detectable tumors. In the $10 \%$ of rat intermammary gland administration of MNU don't caused development tumor.

Macroscopic structure of the mammary gland tissue was composed of fibrotic strands with a small inclusion of fat tissue. Macroscopic structure of the newly formed tissue had the appearance of a node within indistinct borders of the growth, and in some animals with ulcerations and calcification of the skin over the hearth of tumor growth. Histologically in the excised tumors revealed infiltrative duct cancer with precancerous changes in edge zones, intra-ductal proliferation. It was noted the formation of the ductal, glandular cribriform structures lined by moderately pleomorphic epithelium with variable mitotic activity; tubular structures predominated, some areas present mixed nests, trains and groups of individual cells with less formalized channels until their disappearance (Fig. 1).

In, almost all of the analyzed tumors, expression of estrogen receptor- $\alpha$ (ER- $\alpha$ ) and Her2/neu wasn't detected (Fig. 2A and 2B), whereas expression of progesterone receptor (PG) and Ki-67 was detected (Fig. 2C and 2D). The proportion of positive to PG cells was $2 / 3$, score 4 . The intensity of staining of the cell was average, points 2 . Total score of the evaluation of expression by Allred DC (proportion score + intensity score) 6 . Among tumor cells $45 \%$ of them were positive to Ki-67, a marker of proliferative activity.

A

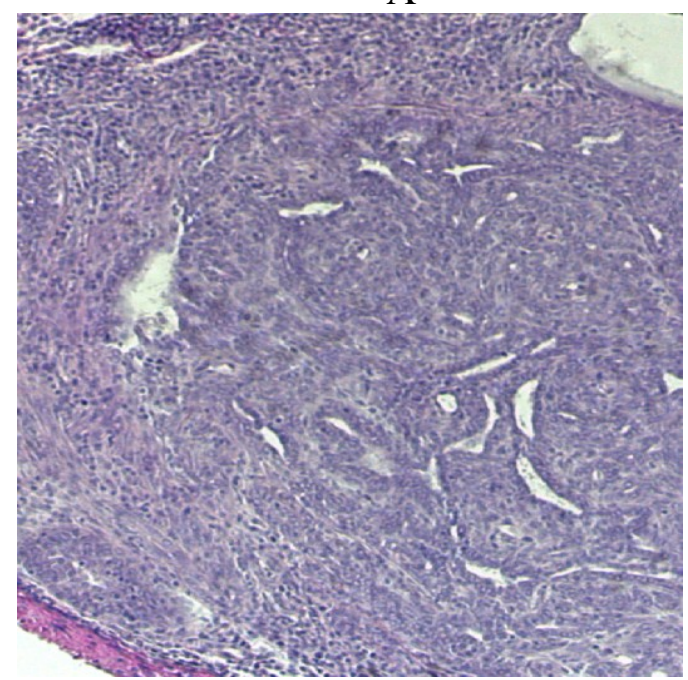

$\mathrm{B}$

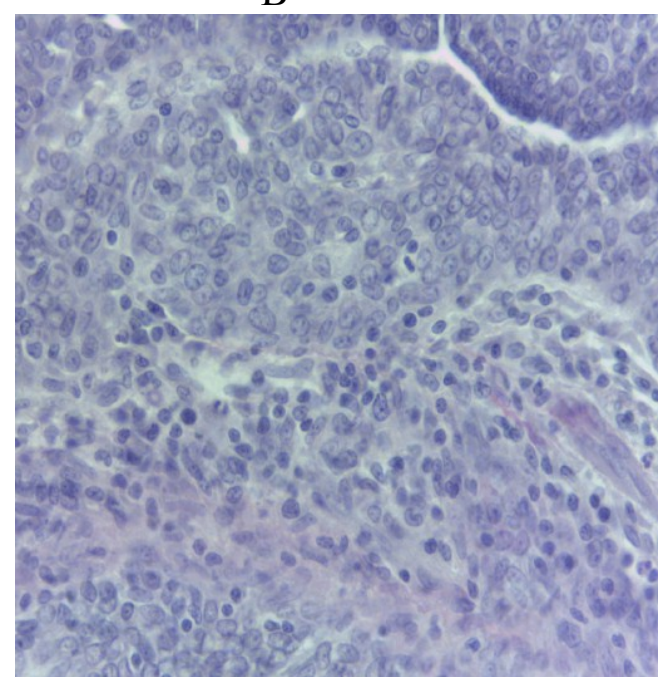

Figure 1. Mammary gland ductal adenocarcinoma (A, x10), (B, x400). Stained cells were visualized using $\mathrm{H} \& \mathrm{E}$. 
A

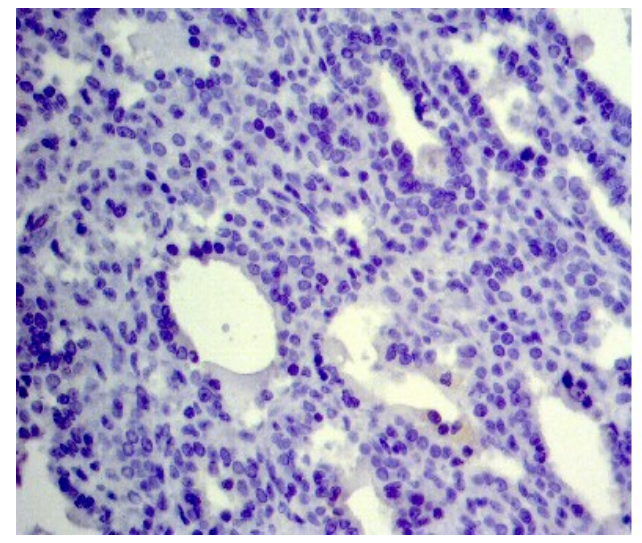

$\mathrm{C}$

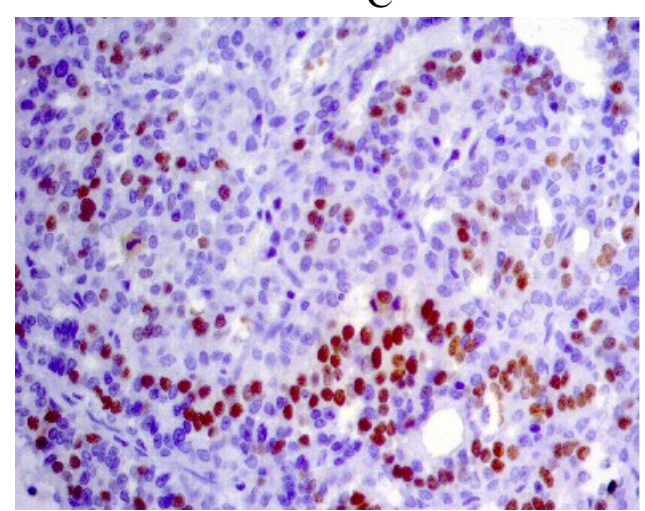

$\mathrm{B}$

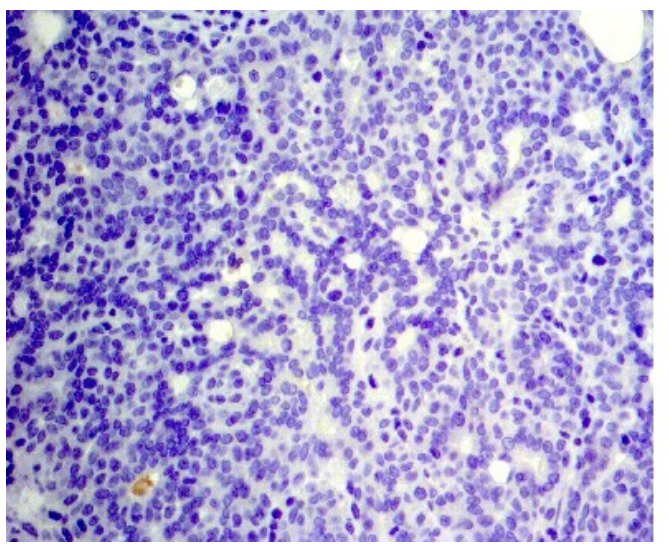

$\mathrm{D}$

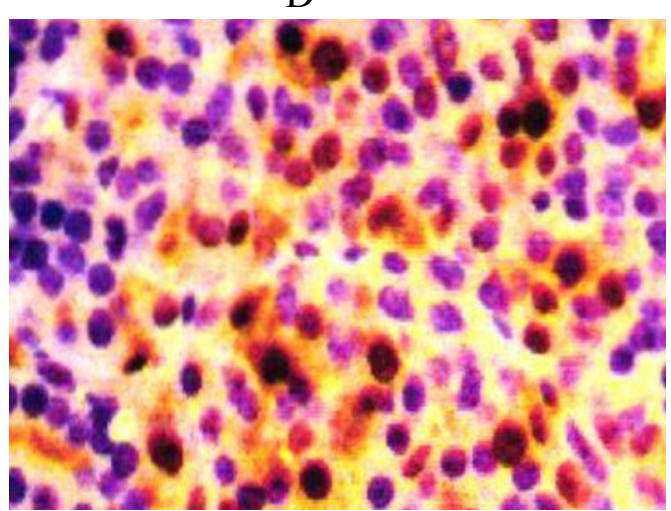

Figure 2. Immunohistochemical staining of MNU-treated mammary gland for estrogen receptor- $\alpha$ (A, X100), Her2/neu (B, X100), progesterone receptor (C, X100) and KI-67 (D, X400). Stained cells were visualized using Novus or Dako kits and counterstained with hematoxylin.

Cells isolated from tumor tissue or from mammary gland tissue was fibroblast-like morphology. We observed intense and widespread expression of CD90 MSC marker, and CD45 marker, which would identify hematopoietic stem cells (Table 1).

Table 1. Quantity and phenotype of mesenchymal stem cells in MNU-induced BC.

\begin{tabular}{|c|c|c|c|c|c|}
\hline & \multicolumn{5}{|c|}{ Mesenchymal stem cells } \\
\hline & \multirow{2}{*}{$\begin{array}{c}\text { Control } \\
\text { Mammary } \\
\text { gland tissue }\end{array}$} & \multicolumn{2}{|c|}{ MNU-induced BC } & \multicolumn{2}{|c|}{ Undeveloped MNU-induced BC } \\
\hline & & Tumor tissue & $\begin{array}{c}\text { Mammary } \\
\text { gland tissue } \\
\text { on } \\
\text { contralateral } \\
\text { side }\end{array}$ & $\begin{array}{l}\text { Mammary } \\
\text { gland tissue }\end{array}$ & $\begin{array}{l}\text { Mammary } \\
\text { gland tissue on } \\
\text { contralateral } \\
\text { side }\end{array}$ \\
\hline \multirow[t]{2}{*}{ Quantity $\left(10^{6}\right)$} & 1,75 & $6,0 *$ & $2,75 \#$ & 2,5 & 1,75 \\
\hline & $1,38-2,13$ & $5,0-7,0$ & $2,5-3,0$ & $2,5-2,5$ & $1,0-2,5$ \\
\hline \multirow{2}{*}{$\begin{array}{c}\mathrm{CD}^{\mathrm{CD}} 5^{+} \mathrm{CD} 90^{-} \\
(\%)\end{array}$} & 0,11 & $4,26^{*}$ & $0,01 * \#$ & 0,96 & 0,04 \\
\hline & $0,08-0,13$ & $2,8-5,72$ & $0,0-0,01$ & $0,03-1,89$ & $0,02-0,06$ \\
\hline \multirow{2}{*}{$\begin{array}{c}\mathrm{CD}^{2} 5^{+} \mathrm{CD} 90^{+} \\
(\%)\end{array}$} & 0,05 & $3,88^{*}$ & $0,02 * \#$ & $0,09 *$ & $0,0 \#$ \\
\hline & $0,05-0,05$ & $3,8-3,96$ & $0,0-0,03$ & $0,01-0,16$ & $0,0-0,0$ \\
\hline \multirow{2}{*}{$\begin{array}{c}\mathrm{CD}^{\circ} \mathrm{CD} 90^{+} \\
(\%)\end{array}$} & 10,24 & $25,99 *$ & $15,24 * \#$ & $5,84^{*}$ & $10,89 \#$ \\
\hline & $10,02-10,47$ & $24,58-27,4$ & $12,93-17,54$ & $5,62-6,01$ & $8,97-12,81$ \\
\hline
\end{tabular}

* - differ with control group, \# - differ with MSC obtained from mammary gland on contralateral side, significant value between group $\mathrm{p}<0.05$. 
In animal with MNU-induced BC the quantity of CD45+CD90- and CD45+CD90+ and CD45-CD90+ MSC was significantly increased compared with control group and mammary gland tissue on contralateral side of the same rats $(p<0.05)$. CD45-CD90+ MSC quantity in animal without developed MNU-induced BC was significantly increased compare with control group and was lower compare to mammary gland tissue on contralateral side of the same rat $(\mathrm{p}<0.05)$. Also, the quantity of CD45+CD90+ MSC was significantly decreased compare with control group and increased compared with mammary gland tissue on contralateral side of the same rat $(\mathrm{p}<0.05)$.

The proliferative potential and NO production by MSC obtained from mammary glands and tumor tissue was studied (Table 2).

So, BC-MSCs proliferation activity was significant increased compared with control group or with MSC from mammary gland tissue from contralateral side of the same animals, whereas MSC proliferative potential obtained from rat with undeveloped MNU-induced BC was significant decreased compare with control group and from MSC obtained from mammary gland tissue on contralateral side of the same animals $(p<0.05)$. In the presence of $\mathrm{H}_{2} \mathrm{O}_{2} \mathrm{MSC}$ proliferative potential from animals with MNU-induced $\mathrm{BC}$ have tendency to decreased compare of basal levels of proliferation but it's was significant increased compare with control group and with MCS proliferation obtained from mammary gland tissue on contralateral side of the same animals $(\mathrm{p}<0.05)$.

MSC obtained from tumor tissue produced significant lower levels of basal or under oxidative stress induced by $\mathrm{H}_{2} \mathrm{O}_{2} \mathrm{NO}$ compare with control group and with MSC obtained from mammary gland tissue on contralateral side of the same animals, whereas in animal with undeveloped MNU-induced BC-MSC produced significant lower levels of basal or under oxidative stress induced by $\mathrm{H}_{2} \mathrm{O}_{2} \mathrm{NO}$ only compare with $\mathrm{MSC}$ obtained from mammary gland tissue on contralateral side of the same animals $(\mathrm{p}<0.05)$.

Table 2. Functional activity of mesenchymal stem cells in MNU-induced BC.

\begin{tabular}{|c|c|c|c|c|c|}
\hline & \multicolumn{5}{|c|}{ Mesenchymal stem cells } \\
\hline & \multirow{2}{*}{$\begin{array}{c}\text { Control } \\
\text { Mammary } \\
\text { gland tissue }\end{array}$} & \multicolumn{2}{|c|}{ MNU-induced BC } & \multicolumn{2}{|c|}{ Undeveloped MNU-induced BC } \\
\hline & & Tumor tissue & $\begin{array}{c}\text { Mammary gland } \\
\text { tissue on } \\
\text { contralateral } \\
\text { side }\end{array}$ & $\begin{array}{c}\text { Mammary } \\
\text { gland tissue }\end{array}$ & $\begin{array}{c}\text { Mammary } \\
\text { gland tissue on } \\
\text { contralateral } \\
\text { side }\end{array}$ \\
\hline \multicolumn{6}{|c|}{ Proliferative potential } \\
\hline \multirow[t]{2}{*}{ basal } & 0,37 & $0,69 *$ & $0,48 \#$ & $0,32 *$ & 0,42 \\
\hline & $0,37-0,37$ & $0,53-0,85$ & $0,37-0,59$ & $0,29-0,36$ & $0,33-0,51$ \\
\hline \multirow[t]{2}{*}{$\mathrm{H}_{2} \mathrm{O}_{2}$} & 0,38 & $0,56^{*}$ & $0,44 \#$ & 0,41 & 0,4 \\
\hline & $0,35-0,42$ & $0,52-0,6$ & $0,37-0,51$ & $0,3-0,52$ & $0,35-0,46$ \\
\hline \multicolumn{6}{|c|}{ NO production } \\
\hline \multirow[t]{2}{*}{ basal } & 20,28 & $18,1^{*}$ & $38,55 \#$ & 15,5 & $21,95 \#$ \\
\hline & $16,15-23,03$ & $18,0-26,2$ & $25,9-51,2$ & $12,3-18,7$ & $21,1-22,8$ \\
\hline \multirow[t]{2}{*}{$\mathrm{H}_{2} \mathrm{O}_{2}$} & 26,25 & $26,2 *$ & $31,45 \#$ & 18,9 & $28,05 \#$ \\
\hline & $21,3-29,55$ & $26,0-26,2$ & $30,3-32,6$ & $16,6-21,2$ & $25,9-30,2$ \\
\hline
\end{tabular}

$\mathrm{H}_{2} \mathrm{O}_{2}$ - presence of $100 \mu \mathrm{M}$ of $\mathrm{H}_{2} \mathrm{O}_{2}$ in culture media, $\mathrm{NO}$ - nitrogen oxide, * - differ with control group, \# - differ with MSC obtained from mammary gland on contralateral side, significant value **between group $\mathrm{p}<0.05$.

As show in Table 3, after chemotherapy in animal with $\mathrm{BC}$ was detected significant increased quantity of mononuclear cells obtained from thorax duct lymph compare with group of animal with $\mathrm{MNU}$-induced $\mathrm{BC}(\mathrm{p}<0.05)$. In all experimental group of animal was indicated significant decreased quantity of BM-MNC compare with control group $(p<0.05)$. 
Vol. 6

Table 3. Quantity of immunocompetent cells in MNU-induced BC.

\begin{tabular}{|c|c|c|c|c|}
\hline Groups & PB-MNC $\left(10^{6}\right)$ & BM-MNC $\left(10^{6}\right)$ & BM-MSC $\left(10^{6}\right)$ & Spleenocytes $\left(10^{6}\right)$ \\
\hline \multirow[t]{2}{*}{ Control } & 4.25 & 210 & 1.2 & 287.5 \\
\hline & $4.25-5$ & $200-215$ & $1.2-1.3$ & $275-300$ \\
\hline \multirow[t]{2}{*}{$\mathrm{BC}$} & 4 & $70 *$ & $0.43 *$ & $262.5^{*}$ \\
\hline & $4-4.3$ & $62.5-75$ & $0,4-0.45$ & $250-275$ \\
\hline \multirow[t]{2}{*}{ Resection } & 6.67 & $166.33 * \#$ & $2.9 * \#$ & $600 * \#$ \\
\hline & $6.67-8$ & $160-163.33$ & $2.9-2.9$ & $600-675$ \\
\hline \multirow[t]{2}{*}{ Resection/CMF } & 6.03 & $153 * \# \$$ & $0.75 * \# \$$ & $119 * \# \$$ \\
\hline & $4.5-7.5$ & $150.25-153$ & $0.75-0.75$ & $102-136$ \\
\hline \multirow[t]{2}{*}{ CMF } & $7.75 \#$ & $87.5^{*} \# \$^{\wedge}$ & $0.75^{*} \# \$$ & $350^{*} \# \$^{\wedge}$ \\
\hline & $5-9.5$ & $87.5-88.75$ & $0.75-0.75$ & $300-400$ \\
\hline \multirow[t]{2}{*}{ fDNA } & 4.4 & $135 * \# \$ \&$ & $1.2 \# \$^{\wedge} \&$ & $350 * \# \$$ \\
\hline & $4-7.5$ & $120-155$ & $1.05-1.2$ & $350-420$ \\
\hline
\end{tabular}

$\mathrm{BC}$ - breast cancer, Resection - group of rat after BC resection, Resection/CMF - group of rat after $\mathrm{BC}$ resection and received CMF (Cyclophosphamide, 5-Fluoracil, Methotrexate), CMF - rat with $\mathrm{BC}$ received only CMF therapy, fDNA - group of rat after $\mathrm{BC}$ resection and received CMF and additional received fragmented exogenous DNA, * - differ with control group, \# - differ with BC group, $\$$ - differ with Resection group, $\wedge$ - differ with Resection/CMF group, \& - differ with CMF group, significant value between groups $\mathrm{p}<0.05$.

Table 4. Proliferative activity of immunocompetent cells from MNU-induced BC.

\begin{tabular}{|c|c|c|c|c|c|c|}
\hline \multirow[t]{2}{*}{ Groups } & \multicolumn{2}{|c|}{ PB-MNC } & \multicolumn{2}{|c|}{ BM-MNC } & \multicolumn{2}{|c|}{ Spleenocytes } \\
\hline & basal & Con A & basal & Con A & basal & Con A \\
\hline \multirow[t]{2}{*}{ Control } & 0.19 & 0.24 & 0.36 & 0.65 & 0.09 & 0.07 \\
\hline & $0.18-0.2$ & $0.21-0.27$ & $0.35-0.36$ & $0.65-0.65$ & $0.07-0.1$ & $0.06-0.07$ \\
\hline \multirow[t]{2}{*}{$\mathrm{BC}$} & $0.3 *$ & 0.25 & $0.37 *$ & $0.56^{*}$ & $0.79 *$ & $0.65 *$ \\
\hline & $0.29-0.31$ & $0.22-0.26$ & $0.37-0.37$ & $0.56-0.57$ & $0.79-0.79$ & $0.65-0.65$ \\
\hline \multirow[t]{2}{*}{ Resection } & $0.24 *$ & 0.29 & $0.46^{*} \#$ & $0.8 * \#$ & $0.4^{*} \#$ & $0.42 * \#$ \\
\hline & $0.23-0.24$ & $0.29-0.3$ & $0.46-0.46$ & $0.8-0.8$ & $0.4-0.4$ & $0.42-0.42$ \\
\hline \multirow[t]{2}{*}{ Resection/CMF } & $0.35^{* \# \$}$ & $0.41 * \# \#$ & $0.13 * \# \$$ & $0.28 * \# \$$ & $0.26^{*} \# \$$ & $0.18 * \# \$$ \\
\hline & $0.35-0.36$ & $0.38-0.45$ & $0.13-0.13$ & $0.27-0.28$ & $0.25-0.26$ & $0.17-0.18$ \\
\hline \multirow[t]{2}{*}{$\mathrm{CMF}$} & $0.22^{\wedge}$ & 0.3 & $0.31^{*} \# \mathbb{S}^{\wedge}$ & $0.28 * \# \$$ & $0.37^{*} \# \$^{\wedge}$ & $0.16^{*} \# \$^{\wedge}$ \\
\hline & $0.21-0.24$ & $0.23-0.37$ & $0.31-0.31$ & $0.28-0.29$ & $0.36-0.37$ & $0.16-0.17$ \\
\hline \multirow[t]{3}{*}{ fDNA } & $0.27 *$ & $0.26 \$$ & $0.23^{*} \# \$^{\wedge}$ & $0.44^{*} \# \mathbb{S}^{\wedge}$ & $0.17^{*} \# \$^{\wedge}$ & $0.15^{*} \# \$^{\wedge}$ \\
\hline & $0.26-0.31$ & $0.21-0.33$ & $\&$ & $\&$ & $\&$ & $\&$ \\
\hline & & & $0.23-0.23$ & $0.43-0.44$ & $0.16-0.17$ & $0.15-0.15$ \\
\hline
\end{tabular}

$\mathrm{BC}$ - breast cancer, Resection - group of rat after BC resection, Resection/CMF - group of rat after $\mathrm{BC}$ resection and received $\mathrm{CMF}$ (Cyclophosphamide, 5-Fluoracil, Methotrexate), CMF - rat with $\mathrm{BC}$ received only CMF therapy, fDNA - group of rat after $\mathrm{BC}$ resection and received $\mathrm{CMF}$ and additional received fragmented exogenous DNA, * - differ with control group, \# - differ with BC group, $\$$ - differ with Resection group, ${ }^{\wedge}$ - differ with Resection/CMF group, $\&$ - differ with CMF group, significant value between groups $\mathrm{p}<0.05$.

Moreover, between experimental groups were estimated difference in quantity of BM-MNC, so was significant decreased count in MNU-induced BC animal and CMF group $(p<0.05)$. In most of experimental animal groups quantity of BM-MSC significantly decreased compare control group $(p<0.05)$. Quantity of spleenocytes in MNU-induced BC depended at the methods of treatment.

As show in Table 4, basal and ConA-induced proliferative potential of immunocompetent cells depended at the methods of treatment in experimental group of animal with MNU-induced 
BC. So, mononuclear cells from thorax duct lymph basal proliferation in most of experimental groups was significantly increased compare with control group, whereas basal and ConA-induced BM-MNC proliferation in most experimental group was significantly decreased compare with control group $(\mathrm{p}<0.05)$. Also, basal and ConA-induced spleenocytes proliferative activity in MNUinduced BC groups was significantly higher compare with control group $(\mathrm{p}<0.05)$.

Levels of thorax duct lymph prolactin in animals received chemotherapy in combination or without combination tumor excision was significantly decreased compare with control group (Table $5 ; \mathrm{p}<0.05)$.

Additional administration to therapy schedule fragmented exogenous DNA possess to significantly increased levels of thyroglobulin in thorax duct lymph compare with control group, $\mathrm{BC}$, Resection, and CMF groups $(\mathrm{p}<0.05)$. The levels of follicle-stimulating hormone were significantly decreased in BC, fDNA groups after excision of tumor tissue compare with control group ( $\mathrm{p}<0.05)$. Also, in animal from $\mathrm{BC}$, Resection/CMF groups after excision of tumor tissue levels of luteinizing hormone was statistically significant decreased compare with control group $(\mathrm{p}<0.05)$. The thorax duct lymph levels of estradiol were significantly decreased in Resection group and CMF group compare with control group $(\mathrm{p}<0.05)$.

Table 5. Levels of hormones in thorax lymph in MNU-induced BC.

\begin{tabular}{|c|c|c|c|c|c|}
\hline Groups & Prolactin & TG & FSG & LG & E $_{2}$ \\
\hline Control & $\frac{544.13}{510.21-578.04}$ & $\frac{6.25}{6.2-6.3}$ & $\frac{19.59}{17.82-21.35}$ & $\frac{5.7}{4.59-6.81}$ & $\frac{526.82}{518.44-535.19}$ \\
\hline BC & $\frac{544.13}{510.21-578.04}$ & $\frac{6.25}{6.2-6.3}$ & $\frac{19.59}{17.82-21.35}$ & $\frac{5.7}{4.59-6.81}$ & $\frac{526.82}{518.44-535.19}$ \\
\hline Resection & $\frac{549.51}{540.13-549.51}$ & $\frac{6.3}{6.19-6.3}$ & $\frac{17.82 * \#}{17.82-17.82}$ & $\frac{4.04 * \#}{4.04-4.04}$ & $\frac{478.02 * \#}{470.02-482.63}$ \\
\hline Resection/CMF & $\frac{492.29 * \# \$}{492.29-492.29}$ & $\frac{6.95}{6.95-6.95}$ & $\frac{16.34}{16.34-16.34}$ & $\frac{5.7 \$}{5.7-6.52}$ & $\frac{444.59}{444.59-444.59}$ \\
\hline CMF & $\frac{524.52 *}{504.84-524.94}$ & $\frac{6.06}{6.06-6.09}$ & $\frac{14.67}{10.01-17.82}$ & $\frac{5.9 \#}{5.28-6.05}$ & $\frac{492.79 \#}{481.54-499.56}$ \\
\hline fDNA & 529.88 & $\frac{7.69 * \# \$ \&}{7.69-8.2}$ & $\frac{18.24 \$}{17.82-19.01}$ & $\frac{6.61}{2.34-6.61}$ & $\frac{469.45}{469.45-524.36}$ \\
\hline
\end{tabular}

$\mathrm{BC}$ - breast cancer, Resection - group of rat after BC resection, Resection/CMF - group of rat after $\mathrm{BC}$ resection and received CMF (Cyclophosphamide, 5-Fluoracil, Methotrexate), CMF - rat with $\mathrm{BC}$ received only CMF therapy, fDNA - group of rat after $\mathrm{BC}$ resection and received $\mathrm{CMF}$ and additional received fragmented exogenous DNA, * - differ with control group, \# - differ with BC group, $\$$ - differ with Resection group, ${ }^{\wedge}$ - differ with Resection/CMF group, $\&$ - differ with CMF group, significant value between groups $\mathrm{p}<0.05$.

Between thoracic duct lymph levels of PRL and $\mathrm{FSH}$, and $\mathrm{LH}$, and $\mathrm{E}_{2}$ was estimated positive links $(\mathrm{R}=0.97, \mathrm{p}=0.00003 ; \mathrm{R}=0.77, \mathrm{p}=0.0029 ; \mathrm{R}=0.9, \mathrm{p}=0.00006$, respectively). Correlation analysis between of the hormones levels in thoracic duct lymph of CMF animals determined the presence of positive interaction of PRL with of $F S H, L H$, and $E_{2}(R=0.9, p=0.002 ; R=0.9, p=0.0021 ; R=0.83$, $\mathrm{p}=0.01$, respectively). Also, between levels of $\mathrm{E}_{2}$ in lymph CMF animals and levels of FSH, and LH was established positive correlation $(\mathrm{R}=0.97, \mathrm{p}=0.00003 ; \mathrm{R}=0.97, \mathrm{p}=0.00004$, respectively).

The levels of miRNA-21 expression in thorax duct lymph no have statistically significant differ between groups of animal (Table 6). In animal from Resection group, Resection/CMF group, CMF group and fDNA group were detected significantly decreased levels of miRNA-221 and miRNA-222 expression compare with control and BC groups $(\mathrm{p}<0.05)$. After tumor excision and chemotherapy in thorax duct lymph observed significantly increased levels of the miRNA-429 expression compare with control-group, whereas significantly decreased compare with Resectiongroup $(\mathrm{p}<0.05)$. In tumor tissue from CMF group established significantly increased expression 
levels of miRNA-21 compare with control group and Resection group $(\mathrm{p}<0.05)$. In $\mathrm{BC}$ group, Resection group, CMF group and fDNA group were detected significantly decreased expression levels of miRNA-221 and miRNA-222 compare with control group $(\mathrm{p}<0.05)$.

Serum levels expression of miRNA-21 in animal from fDNA group was significantly increased compare with control, Resection/CMF and CMF groups $(\mathrm{p}<0.05)$. Serum levels expression of miRNA-221 in BC, Resection and fDNA groups were significantly increased compare with control group, whereas increased in Resection/CMF, CMF and fDNA groups compare with BC group $(\mathrm{p}<0.05)$. Significantly elevated expression levels of miRNA-222 were detected in serum from CMF and fDNA groups compare with control group $(p<0.05)$. Also, in serum from $\mathrm{BC}$ and fDNA groups was detected significantly decreased expression levels of miRNA-429 compare with control group $(\mathrm{p}<0.05)$.

Table 6. Expression of pro-oncogenic and anti-oncogenic miRNA in MNU-induced BC.

\begin{tabular}{|c|c|c|c|c|c|c|c|}
\hline \multicolumn{2}{|c|}{ miRNA } & Control & $\mathrm{BC}$ & Resection & Resection/CMF & CMF & fDNA \\
\hline \multirow{4}{*}{$\vec{\sim}$} & \multirow{8}{*}{ 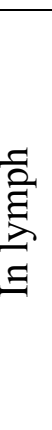 } & 5.25 & 7.55 & 17.56 & 42.98 & 15.83 & 31.77 \\
\hline & & $\overline{0.02-11.76}$ & $5.25-11.76$ & $\overline{14.07-18.38}$ & $35-383.12$ & $15.54-16.93$ & $28.71-32.81$ \\
\hline & & 3.16 & 3.2 & $0.07 * \#$ & $0.56 \# \$$ & $0.15 \#$ & $0.83 \#^{\wedge}$ \\
\hline & & $\overline{2.5-3.2}$ & $3.16-3.71$ & $0.07-0.16$ & $0.41-0.59$ & $0.14-4.71$ & $0.72-1.14$ \\
\hline \multirow{2}{*}{$\underset{\sim}{\widetilde{N}}$} & & 1.35 & 1.24 & $0.35 * \#$ & $0.01 * \#$ & $0.25 * \#$ & $0.46^{\wedge} \&$ \\
\hline & & $0.53-1.87$ & $0.53-1.35$ & $0.34-0.5$ & $0-0.05$ & $0.22-0.29$ & $0.44-0.7$ \\
\hline \multirow{2}{*}{ 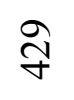 } & & 36.27 & 45.64 & 5.68 & 52.95\# & $14.84 \$$ & 40.36 \\
\hline & & $1.71-52.23$ & $36.27-52.23$ & $4.92-6.73$ & $1.2-73.74$ & $11.65-22.66$ & $29.58-44.84$ \\
\hline \multirow{2}{*}{$\bar{\sim}$} & \multirow{8}{*}{ 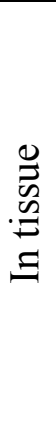 } & 1.19 & 0.31 & 13.74 & 1.26 & $0.25^{*} \# \$$ & $13.74 \&$ \\
\hline & & $0.54-1.42$ & $0.3-0.33$ & $0.3-23.51$ & $0.06-1.27$ & $0.24-0.26$ & $0.3-23.51$ \\
\hline \multirow{2}{*}{$\overrightarrow{\widetilde{N}}$} & & 1.52 & $0.06^{*}$ & $0.06^{*}$ & 0.59 & $0.06^{*}$ & $0.06 * \$$ \\
\hline & & $0.33-1.82$ & $0.06-0.07$ & $0.06-0.07$ & $\overline{0.01-0.6}$ & $0.06-0.07$ & $0.06-0.07$ \\
\hline \multirow{2}{*}{ } & & 2.87 & $0.01 *$ & $0.01 *$ & $0.73 \# \$$ & $0.01 * \# \$$ & $0.01^{* \wedge} \&$ \\
\hline & & $0.13-3.33$ & $0-0.01$ & $0-0.01$ & $0.01-0.73$ & $0.01-0.02$ & $0-0.01$ \\
\hline \multirow{2}{*}{$\stackrel{\overbrace{}}{\Im}$} & & 4.59 & 2.56 & 2.56 & 0.01 & 0.07 & 2.56 \\
\hline & & $0.01-5.04$ & $1.93-3.8$ & $1.93-3.8$ & $0.01-1.74$ & $0.07-0.12$ & $1.93-3.8$ \\
\hline \multirow{2}{*}{$\vec{\sim}$} & \multirow{8}{*}{$\begin{array}{l}\Xi \\
\Xi \\
\bar{\Xi} \\
\Xi \\
\Xi\end{array}$} & 1.29 & 2.08 & 2.08 & 0.21 & 0.84 & $1.98^{* \wedge} \&$ \\
\hline & & $0.53-1.37$ & $0.48-3.38$ & $0.48-3.38$ & $0.16-1.01$ & $0.5-1.14$ & $1.96-3.77$ \\
\hline \multirow{2}{*}{$\overrightarrow{\widetilde{N}}$} & & 1.3 & $6.39 *$ & $6.39 *$ & $3.02 \# \$$ & $1.2 \# \$$ & $13.91 * \# \$^{\wedge} \&$ \\
\hline & & $1.21-1.93$ & $6.03-7.87$ & $6.03-7.87$ & $1.29-4.66$ & $0.7-1.61$ & $11.49-57.13$ \\
\hline \multirow{2}{*}{ તิ } & & 0.26 & 3.01 & 3.01 & 0.29 & $1.06^{*}$ & $1.2^{* \wedge}$ \\
\hline & & $0.01-0.3$ & $0.14-4.86$ & $0.14-4.86$ & $0.23-0.59$ & $0.32-1.72$ & $1.14-1.23$ \\
\hline \multirow{2}{*}{$\stackrel{\overbrace{}}{ナ}$} & & 3.25 & $0 *$ & $0 *$ & 0 & $0.1^{*}$ & $0.05 *$ \\
\hline & & $2.23-3.58$ & $\overline{0-0.07}$ & $\overline{0-0.07}$ & $\overline{0-2.66}$ & $\overline{0.09-0.11}$ & $\overline{0.01-0.05}$ \\
\hline
\end{tabular}

$\mathrm{BC}$ - breast cancer, Resection - group of rat after BC resection, Resection/CMF - group of rat after $\mathrm{BC}$ resection and received CMF (Cyclophosphamide, 5-Fluoracil, Methotrexate), CMF - rat with $\mathrm{BC}$ received only CMF therapy, fDNA - group of rat after $\mathrm{BC}$ resection and received $\mathrm{CMF}$ and additional received fragmented exogenous DNA, * - differ with control group, \# - differ with BC group, $\$$ - differ with Resection group, $\wedge$ - differ with Resection/CMF group, \& - differ with CMF group, significant value between groups $\mathrm{p}<0.05$.

Correlation analysis between the expression levels of miRNAs in thoracic duct lymph of control group estimated positive link of miRNA-21 with miRNA-429 $(\mathrm{R}=0.83, \mathrm{p}=0.005)$. Between the expression levels of miR-21 and miR-221 in lymph of BC animals obtained negative relation $(\mathrm{R}=-0.66, \mathrm{p}=0.018)$. In Resection group was obtained correlations of the expression levels of miRNA-21 with miRNA-222 $(\mathrm{R}=0.73, \mathrm{p}=0.024)$, between miRNA-221 and miRNA-222 $(\mathrm{R}=0.71$, $\mathrm{p}=0.01$ ), between expression of miRNA-429 with miRNA-221, and with miRNA-222 (R0.72, 
$\mathrm{p}=0.008 ; \mathrm{R}=0.68, \mathrm{p}=0.013$, respectively). Also, we found the presence of correlation between the expression levels of miRNA-21 and miRNA-221 $(\mathrm{R}=0.72, \mathrm{p}=0.029)$ in Resection/CMF group, and between expression of miRNA-221 and miRNA-429 $(\mathrm{R}=0.79, \mathrm{p}=0.002)$ in $\mathrm{CMF}$ animal group.

Moreover, between thoracic duct lymph levels of hormones and expression levels of miRNAs we established some correlations. So, the expression levels of miRNA-222 negatively correlate with the lymph levels of FSH, and with the lymph levels of $E_{2}(R=-0.69, p=0.012 ; R=-0.66, p=0.018$, respectively) in $\mathrm{BC}$ group. In -Resection group the expression levels of miRNA-21 positively correlate with the lymphatic levels of PRL, TG, FSH, and $\mathrm{LH}(\mathrm{R}=0.94, \mathrm{p}=0.005)$, and negatively with the levels of $\mathrm{E}_{2}(\mathrm{R}=-0.94, \mathrm{p}=0.005)$. Between the expression levels of miRNA-429 in Resection/CMF group and the levels of PRL, TG, FSH, and LH was estimated positive correlation $(\mathrm{R}=0.9, \mathrm{p}=0.002)$, and negative relationships with the levels of $\mathrm{E}_{2}(\mathrm{R}=-0.9, \mathrm{p}=0.002)$.

In MNU-induced BC animal in blood serum were detected significantly elevated levels of IL$1 \beta$, IL-2, IL-4, IL-6, IL-7, IL-12, IL-13, IL-17A, INF $\gamma$, MIP-1 $\alpha$, MIP-3 $\alpha$, RANTES, TNF $\alpha$ and MCP-1, whereas levels of IL-1 $\alpha$, IL-5, IL-10, IL-18, GRO/KC and VEGF were significantly decreased compare with control group (Table $7 ; p<0.05$ ). After only excision of tumor tissue in blood serum of animals were observed significantly increased levels of IL-6, TNF $\alpha$ and significantly decreased levels of IL-10, IL-18, GRO/KC compare with control $(\mathrm{p}<0.05)$.

Table 7. Serum levels of cytokine in MNU-induced BC.

\begin{tabular}{|c|c|c|c|c|c|c|}
\hline Cytokines & Control & $\mathrm{BC}$ & Resection & Resection/CMF & $\mathrm{CMF}$ & fDNA \\
\hline \multirow[t]{2}{*}{ IL-1alpha } & 48.82 & 75.38 & $20.3 \#$ & $29.19 \#$ & $43.36 \# \$$ & $33.8 \#$ \\
\hline & $\overline{16.5-70.9}$ & $\begin{array}{l}46.65- \\
75.38\end{array}$ & $\begin{array}{l}13.25- \\
20.3\end{array}$ & $23.6-34.11$ & $\begin{array}{l}27.34- \\
43.36\end{array}$ & $16.22-38.7$ \\
\hline \multirow[t]{2}{*}{ IL-1beta } & 35.71 & $402.24^{*}$ & 41.43\# & $53.73 * \# \$$ & $48.61 * \# \$$ & $35.71 \#^{\wedge} \&$ \\
\hline & $\begin{array}{l}27.63- \\
42.75\end{array}$ & $\begin{array}{l}300.13- \\
466.59\end{array}$ & $\begin{array}{l}26.38- \\
41.73\end{array}$ & $\overline{53.05-70.01}$ & $\begin{array}{l}46.88- \\
49.17\end{array}$ & $28.47-42.61$ \\
\hline \multirow[b]{2}{*}{ IL-2 } & 82.34 & $401.41^{*}$ & $73.3 \#$ & $106.7 \# \$$ & $226.25 * \$$ & $209.79 * \# \$$ \\
\hline & $\begin{array}{l}82.34- \\
136.87\end{array}$ & $\begin{array}{l}226.17- \\
402.64\end{array}$ & $\begin{array}{l}66.44- \\
85.3\end{array}$ & $104.2-147.65$ & $\overline{146.76-366}$ & $\overline{136.87-209.79}$ \\
\hline \multirow{2}{*}{ IL-4 } & 39.5 & $68^{*}$ & $20.2 \#$ & $31.4 * \#$ & $42.22 \# \$^{\wedge}$ & $116.3^{*} \# \$^{\wedge} \&$ \\
\hline & $\overline{37.82-43.2}$ & $\overline{67.2-82.3}$ & $18.2-26.8$ & $28.4-32.8$ & $40.22-51.1$ & $104.36-164.36$ \\
\hline \multirow[b]{2}{*}{ IL-5 } & 137.82 & 175.41 & 93.93 & $33.17 * \# \$$ & $83.11^{\wedge}$ & $176.78 \$^{\wedge} \&$ \\
\hline & $\begin{array}{l}118.85- \\
170.23\end{array}$ & $\begin{array}{l}128.32- \\
205.2\end{array}$ & $\begin{array}{l}79.72- \\
128.32\end{array}$ & $28.32-34.23$ & $\begin{array}{l}82.22- \\
161.45\end{array}$ & $165.17-179.72$ \\
\hline \multirow[b]{2}{*}{ IL-6 } & 310.47 & $1667.7^{*}$ & 843.1 *\# & $442.66 \# \$$ & $416.54 * \#$ & $980.1 * \#$ \\
\hline & $\begin{array}{l}200.34- \\
330.47\end{array}$ & $\begin{array}{l}1556.39- \\
1777.8\end{array}$ & $\begin{array}{l}487.67- \\
850.1\end{array}$ & $346.4-442.66$ & $\begin{array}{l}392.4- \\
626.5\end{array}$ & $\overline{577.96-1027.7}$ \\
\hline \multirow[b]{2}{*}{ IL-7 } & 128.2 & $442.05^{*}$ & $122.31 \#$ & $100.8 \#$ & $126.25 \# \$^{\wedge}$ & $179.8 \#^{\wedge}$ \\
\hline & $\begin{array}{l}110.13- \\
228.2\end{array}$ & $\begin{array}{l}435.32- \\
494.09\end{array}$ & $\begin{array}{l}116.8- \\
122.56\end{array}$ & $61.95-110.5$ & $\begin{array}{l}126.25- \\
266.1\end{array}$ & $122.65-183.46$ \\
\hline \multirow[b]{2}{*}{ IL-10 } & 1465.99 & $364.48^{*}$ & $447.63^{*}$ & $1016 * \# \$$ & $129.06 * \$$ & $1274.1 \#^{\wedge} \&$ \\
\hline & $\begin{array}{l}1465.99- \\
2207.07\end{array}$ & $\begin{array}{l}198.99- \\
499.68\end{array}$ & $\begin{array}{l}411.4- \\
727.06\end{array}$ & $96.21-102.09$ & $\begin{array}{l}119.41- \\
178.6\end{array}$ & $\begin{array}{l}1245.89- \\
1661.26\end{array}$ \\
\hline \multirow{2}{*}{ IL-12 } & 75.93 & $131.7^{*}$ & $80 \#$ & 79.6\# & $126^{*} \$^{\wedge}$ & $101.6^{*} \$^{\wedge}$ \\
\hline & $40-80$ & $90-189.7$ & $70-80$ & $72.6-80.7$ & $121-132$ & $100.9-128.4$ \\
\hline \multirow[b]{2}{*}{ IL-13 } & 12.72 & $159.53 *$ & $18.51 \#$ & 15.32\# & $92.72 * \# \$^{\wedge}$ & $511.6^{*} \$^{\wedge} \&$ \\
\hline & $10-26.54$ & $\begin{array}{l}157.67- \\
610.13\end{array}$ & $\begin{array}{l}16.61- \\
18.78\end{array}$ & $\frac{15.32+t}{14.1-21.64}$ & $\frac{92.12 \cdot 48}{88-98}$ & $\frac{511.0 \times \alpha}{433.11-520.39}$ \\
\hline \multirow[b]{2}{*}{ IL-17a } & 33.14 & $243.3^{*}$ & $142.6^{*}$ & $71.2 * \$$ & $71.4 \$$ & $169.8^{* \wedge} \&$ \\
\hline & $\begin{array}{l}33.14- \\
49.79\end{array}$ & $\begin{array}{l}143.7- \\
341.4\end{array}$ & $\begin{array}{l}137.5- \\
142.9\end{array}$ & $62.7-73.8$ & $46.28-90.3$ & $\overline{142.07-189.5}$ \\
\hline
\end{tabular}


Vol. 6

\begin{tabular}{|c|c|c|c|c|c|c|}
\hline IL-18 & $\begin{array}{l}4740.97 \\
4590.89- \\
5276.72\end{array}$ & $\begin{array}{l}\frac{2468.71^{*}}{2268.96-} \\
3345.73\end{array}$ & $\begin{array}{l}\frac{1130.09 * \#}{1071.47-} \\
1151.34\end{array}$ & $\begin{array}{l}\frac{1290.1 *}{1206.78-} \\
2016.91\end{array}$ & $\begin{array}{l}\frac{1513.13^{*} \#}{1090.38-} \\
1851.24\end{array}$ & $\begin{array}{l}7159.91 \# \$^{\wedge} \& \\
5953.32- \\
8878.37\end{array}$ \\
\hline \multirow[b]{2}{*}{ Epo } & 848 & 305.96 & 626.8 & 666.27 & $76.78^{*} \# \$^{\wedge}$ & \multirow{2}{*}{$\frac{349.96}{41.4-746.43}$} \\
\hline & $\begin{array}{l}665.28- \\
1167.65\end{array}$ & $\begin{array}{l}250.68- \\
594.19\end{array}$ & $\begin{array}{l}566.48- \\
1136.69\end{array}$ & $317.07-728.55$ & $64.2-84.33$ & \\
\hline \multirow[b]{2}{*}{$\mathrm{GRO} / \mathrm{KC}$} & 29,2 & $11.92 *$ & $11.2 *$ & \multirow{2}{*}{$\frac{88.5 * \# \$}{0.25 .100 .20}$} & $11 * \wedge$ & $100.63 * \# \$ \&$ \\
\hline & $24.6-33.26$ & $\begin{array}{l}11.09- \\
17.08\end{array}$ & $\begin{array}{l}10.72- \\
21.83\end{array}$ & & $\frac{11}{10.03-12}$ & $\frac{100.05 \text { त } 4 \text { Q }}{99.38-135.17}$ \\
\hline \multirow{2}{*}{ INF-g } & 66.9 & $\frac{140.6 *}{120.60}$ & \multirow{2}{*}{$\frac{26.81 \#}{267-842}$} & $31.3 * \#$ & $77.2 \#^{\wedge}$ & $91.1 \#^{\wedge}$ \\
\hline & $54.2-68.5$ & $\begin{array}{l}129.69- \\
160.5\end{array}$ & & $20.4-42.1$ & $\overline{69.4-88.3}$ & $88.1-104.8$ \\
\hline \multirow[b]{2}{*}{ M-CSF } & 149.9 & 174.52 & 162.93 & 114.52\# & $57.7^{*} \# \$^{\wedge}$ & \multirow{2}{*}{$\frac{114.49 \&}{97.65-142.94}$} \\
\hline & $\begin{array}{l}148.57- \\
186.79\end{array}$ & $\begin{array}{l}157.08- \\
186.97\end{array}$ & $\begin{array}{l}131.81- \\
172.05\end{array}$ & $113.87-154.66$ & $\frac{1.1}{48.1-58.33}$ & \\
\hline \multirow[b]{2}{*}{ MIP-1a } & 1555.89 & $3528.23^{*}$ & 1754.91\# & $1700.7 \#$ & 1737.42\# & \multirow{2}{*}{$\frac{2500.1}{2387.2-2873.47}$} \\
\hline & $\begin{array}{l}1406.28- \\
1594.38\end{array}$ & $\begin{array}{l}3142.96- \\
3549.64\end{array}$ & $\begin{array}{l}1295.36- \\
2282.15\end{array}$ & $\begin{array}{l}1370.38- \\
1940.93\end{array}$ & $\begin{array}{l}1700.1- \\
2119.04\end{array}$ & \\
\hline \multirow[b]{2}{*}{ MIP-3a } & 128.2 & $307.5^{*}$ & 72.1 *\# & $78.5 * \#$ & 141.6\# & $144.12 \$^{\wedge}$ \\
\hline & $\begin{array}{l}121.6- \\
150.3 \\
\end{array}$ & $\begin{array}{l}250.1- \\
333.33 \\
\end{array}$ & $\begin{array}{l}38.13- \\
92.13 \\
\end{array}$ & $55.6-90.4$ & $71.4-142.6$ & $\overline{128.6-314.1}$ \\
\hline \multirow[b]{2}{*}{ RANTES } & 276.52 & $601.54 *$ & $194.99 * \#$ & & \multirow{2}{*}{$\begin{array}{l}\frac{221.46^{*} \#^{\wedge}}{157.51-} \\
231.6\end{array}$} & \multirow{2}{*}{$\frac{580.69 \$ \&}{511.82-680.4}$} \\
\hline & $\begin{array}{l}276.52- \\
513.58\end{array}$ & $\begin{array}{l}536.88- \\
639.86\end{array}$ & $\begin{array}{l}191.6- \\
207.2\end{array}$ & $\frac{40 / .58}{455.1-520.1}$ & & \\
\hline \multirow{2}{*}{$\begin{array}{l}\text { TNF- } \\
\text { alpha }\end{array}$} & 22.35 & $90.42 *$ & 61.74\# & $44.3^{* \#}$ & $88.9 * \wedge$ & $49.1 *$ \\
\hline & $20.65-24.1$ & $\begin{array}{l}87.01- \\
90.96 \\
\end{array}$ & $\begin{array}{l}40.3- \\
67.22 \\
\end{array}$ & $31.4-46.89$ & $\begin{array}{l}70.56- \\
127.9 \\
\end{array}$ & $42.6-80.6$ \\
\hline \multirow[b]{2}{*}{ VEGF } & 100.6 & $68.56^{*}$ & $67.4^{*}$ & $43.47 * \#$ & $60 * \wedge$ & $43.03 *$ \\
\hline & $\begin{array}{l}76.4- \\
133.02\end{array}$ & $67.06-69.4$ & $\begin{array}{l}41.09- \\
68.78\end{array}$ & $\frac{45.4 / \pi}{33.08-44.08}$ & $58.6-66.7$ & $\frac{45.05}{42.37-45.18}$ \\
\hline & 624.14 & $777.9 *$ & $1520.67 *$ & & 767.79 & 620.3 \\
\hline MCP-1 & $\begin{array}{l}477.82- \\
747.32\end{array}$ & $\begin{array}{l}767.79- \\
935.57\end{array}$ & $\begin{array}{l}846.97- \\
1554.58\end{array}$ & $\frac{531.53-612.59}{53}$ & $\begin{array}{l}695.36- \\
846.97\end{array}$ & $605.2-851.34$ \\
\hline
\end{tabular}

$\mathrm{BC}$ - breast cancer, Resection - group of rat after BC resection, Resection/CMF - group of rat after $\mathrm{BC}$ resection and received $\mathrm{CMF}$ (Cyclophosphamide, 5-Fluoracil, Methotrexate), $\mathrm{CMF}$ - rat with $\mathrm{BC}$ received only CMF therapy, fDNA - group of rat after $\mathrm{BC}$ resection and received $\mathrm{CMF}$ and additional received fragmented exogenous DNA, * - differ with control group, \# - differ with BC group, $\$$ - differ with Resection group, $\wedge$ - differ with Resection/CMF group, \& - differ with CMF group, significant value between groups $\mathrm{p}<0.05$.

In blood serum of animals received surgical treatment with chemotherapy were estimated significantly increased levels of IL-1 $\beta$, IL- 6 and TNF $\alpha$, whereas levels of IL-5, IL-10, IL-18, $\mathrm{GRO} / \mathrm{KC}$ and VEGF were significantly decreased compare with control $(\mathrm{p}<0.05)$. In fDNA group blood serum levels of IL-2, IL-4, IL-6 and TNF $\alpha$ were significantly increased, whereas levels of IL$1 \alpha$ were significantly decreased compare with control $(\mathrm{p}<0.05)$.

After chemotherapy in animals with MNU-induced BC in blood serum were detected significantly increased levels of IL-1 $\beta$, IL-2, IL-6 and TNF $\alpha$, whereas levels of IL-1 $\alpha$, IL-10, IL-18, $\mathrm{EPO}, \mathrm{GRO} / \mathrm{KC}$ and VEGF were significantly decreased compare control $(\mathrm{p}<0.05)$. Moreover, additional administration exogenous DNA to treatment schedule saved blood serum levels of IL-10 and IL-18at the levels as in control animals. 
As show in Table 8, the quantity of macrophages in axillaries lymph node in all experimental animal groups were significantly higher compare with control animals $(\mathrm{p}<0.05)$.

Table 8. Macrophages and tumor cells in lymph node in MNU-induced BC.

\begin{tabular}{|c|c|c|c|c|c|c|}
\hline \multirow[t]{2}{*}{ Groups } & \multicolumn{2}{|c|}{ Axillaries lymph node } & \multicolumn{2}{|c|}{ Mesenteric lymph node } & \multicolumn{2}{|c|}{ Sternal lymph node } \\
\hline & Mf & $\mathrm{TC}$ & Mf & $\mathrm{TC}$ & Mf & TC \\
\hline \multirow[t]{2}{*}{ Control } & 10 & 0 & 11 & 0 & 4 & 0 \\
\hline & $9-11$ & $0-0$ & $10-12$ & $0-0$ & $3-5$ & $0-0$ \\
\hline \multirow[t]{2}{*}{$\mathrm{BC}$} & $19^{*}$ & $4 *$ & $18^{*}$ & 1 & $18^{*}$ & 0 \\
\hline & $19-20$ & $2-4$ & $18-20$ & $0-1$ & $17-18$ & $0-0$ \\
\hline \multirow[t]{2}{*}{ Resection } & $13 * \#$ & $4 *$ & $12 \#$ & 0 & $13 * \#$ & 0 \\
\hline & $\overline{13-17}$ & $\overline{3-4}$ & $12-13$ & $\overline{0-0}$ & $12-14$ & $\overline{0-0}$ \\
\hline \multirow[t]{2}{*}{ Resection/CMF } & $18 *$ & $0 \# \$$ & $16 * \# \$$ & 0 & $13 *$ & 0 \\
\hline & $18-21$ & $0-0$ & $13-16$ & $0-0$ & $12-21$ & $0-0$ \\
\hline \multirow[t]{2}{*}{$\mathrm{CMF}$} & $14^{*} \#^{\wedge}$ & $1 \# \$$ & $6^{*} \# \mathbb{S}^{\wedge}$ & 0 & $15 * \#$ & 0 \\
\hline & $12-15$ & $\overline{0-1}$ & $5-8$ & $0-1$ & $14-15$ & $0-0$ \\
\hline \multirow[t]{2}{*}{ fDNA } & $14^{*} \#^{\wedge}$ & $0 \# \$$ & $13 * \# \&$ & 0 & $15 * \#$ & 0 \\
\hline & $13-15$ & $0-0$ & $13-13$ & $0-0$ & $13-16$ & $0-0$ \\
\hline
\end{tabular}

$\mathrm{BC}$ - breast cancer, Resection - group of rat after $\mathrm{BC}$ resection, Resection/CMF - group of rat after $\mathrm{BC}$ resection and received $\mathrm{CMF}$ (Cyclophosphamide, 5-Fluoracil, Methotrexate), $\mathrm{CMF}-$ rat with $\mathrm{BC}$ received only $\mathrm{CMF}$ therapy, fDNA - group of rat after $\mathrm{BC}$ resection and received CMF and additional received fragmented exogenous DNA, * - differ with control group, \# - differ with BC group, $\$$ - differ with Resection group, $\wedge$ - differ with Resection/CMF group, \& - differ with CMF group, significant value between groups $\mathrm{p}<0.05$.

Also, quantity of macrophages in axillaries node from BC group was significantly higher compare with Resection group, CMF group and fDNA group $(p<0.05)$. Whereas, quantity of tumor cells in axillaries lymph node was significantly increased in BC group and Resection group compare with control group, whereas quantity of tumor cells in axillaries lymph node obtained from Resection/CMF, CMF or fDNA groups were significantly lower compare with $B C$ group $(\mathrm{p}<0.05)$.

Also, were obtained significantly increased quantity of macrophages in sternal lymph node in all experimental group compare with control, whereas quantity of macrophages in mesenteric lymph node were significantly increased in $\mathrm{BC}$, Resection/CMF, CMF and fDNA groups compare with control $(\mathrm{p}<0.05)$. Also, we estimated significant lower quantity of macrophages in sternal and mesenteric lymph node in Resection, Resection/CMF, CMF, fDNA groups compare with BC group $(p<0.05)$. We have not fined tumor cells in sternal or mesenteric lymph node in all experimental groups of animals.

\section{Discussion}

In this article we examined rat mammary tumor induced by fifth time intermammary administration of $30 \mathrm{mg} / \mathrm{kg}$ of MNU (summary dose of MNU $150 \mathrm{mg} / \mathrm{kg}$ ). Usually for MNUinduced BC MNU injected in dose $180 \mathrm{mg} / \mathrm{kg}$ or $>$ by once intraperitoneal injection [2, 5]. Although, intermammary administration of MNU induced tumor formation in $90 \%$, but in all cases it's developed in same mammary gland. Obtained quantity of MNU-induced tumor formation a consistent with results obtained by other researcher, whom also induced BC formation of animals by intermammary administration of $\mathrm{MNU}$ - in $92 \%$ [15]. The causes of resistance to the development of $\mathrm{BC}$ after intermammary $\mathrm{MNU}$ injection are poorly studied. The basis of resistance to the action of NMN in Wistar rats may be a genetic heterogeneity of these animals, and as a consequence different levels of sex hormones involved in carcinogenesis in tumors of the mammary glands, as well as the number of MSC in breast tissue and their morphological and functional properties 
Intermammary administration of MNU caused development of infiltrative duct cancer with precancerous changes in edge zones. For characterization the biology of $\mathrm{BC}$ ewe analyzed the expression ER- $\alpha, \mathrm{PG}, \mathrm{Her}$ /neu and marker of cell proliferative activity Ki-67. In our case we found that $\mathrm{BC}$ was positive for PG-R and characterized by an increased proliferative activity as measured by the Ki-67, whereas negative for ER- $\alpha$ and Her2/neu. It's known that in human breast cancer were divided into several phenotypes according to the gene expression profile of ER- $\alpha, \mathrm{PG}$, Her2/neu [6]. MNU-induced breast cancer in animal has ER-/PG+/Her2/neu- phenotype and therefore has common feature with human luminal B subtype of breast cancer. Our result concerning to the expression of steroid receptors are in concordance with results obtained by other researchers, whom shown the presence of ER- $\alpha$ and in BC induced by intraperitoneal administration of MNU [2]. Also, observed increased proliferative activity (Ki-67 positive cells) in animal with intermammary MNU-induced breast cancer was higher than it usually found in animal with breast cancer induced by intraperitoneal MNU administration [2]. The higher Ki-67 value is an important parameter of a poor prognosis in human breast cancer [16]. MNU does not require metabolic activation to exert mutagenic effects and when it administered intermammary the mutagenic effects observed only in mammary gland, whereas intraperitoneal administration of MNU induced carcinogenesis not only in mammary gland and also in other organs.

It is known that the tumor-associated microenvironment, including MSC, plays an important role in carcinogenesis [12-14]. In MNU-induced breast cancer animal we found increased quantity of MSC compare with MSC quantity in normal animal and from mammary gland tissue on contralateral side in BC-bearing animal, whereas CD45-CD90+ MSC count in animal without developed breast cancer after intermammary administration of MNU was significantly lower compare with MNU-induced breast cancer animals. Also, MSC from animal with MNU-induced breast cancer share a high proliferative activity, whereas in animal with undeveloped breast cancer under intermammary MNU administration MSC proliferation was decreased. Under oxidative stress condition MSC from animal with MNU-induced breast cancer share increased proliferation. The levels of NO production by MSC from MNU-induced breast cancer animals was decreased compare with it levels in normal animal or from MSC obtained from contralateral side. It is shown that tumor-associated fibroblasts and MSC initiate a pro-inflammatory microenvironment in the growth of tumor cells, and thus, the type of chronic inflammation initiated conditions for malignant transformation of breast cells [17]. It is also known that MSC have tropism to tumors, promote their growth and metastasis [18]. On the basis of this effect lies MSC paracrine effect of secreted factors of MSC, leading to reduced expression of E-cadherin and increased expression of proteins required for epithelial-mesenchymal transition, in particular, N-cadherin, fibronectin and vimentin [18]. About the role secreted by MSC isolated from breast tumors, according to work [19] where it was shown that conditioned medium from MSC activates proliferative and migratory potential of MSC. In vitro, the authors found anti-proliferative effect of conditioned media on tumor cell lines, as a result of the delay in the G0/G1 phase of the cell cycle, but this effect is not installed in vivo. It is also shown that MSC from breast tissue contribute to penetration of the extracellular matrix components indirectly through the expression of MMP-1 and MPP-3, thereby contribute to invasion of tumor cells [20].

To assess the role of different methods of therapy, chemotherapy or surgical excision or combination of chemotherapy and surgical excision or effect of additional administration of exogenous DNA on quantity and quality of immunocompetent cells in thorax duct lymph, and bone marrow, and spleen in MNU-induced breast cancer animals to determine which is more effective. We found that CMF alone possess to increase count of lymphocytes in thorax duct lymph compare with other treatment groups. Chemotherapy also led to decrease count of bone marrow mononuclear cells, bone marrow mesenchymal stem cells, whereas count of spleenocytes increased. Additional administration of exogenous DNA does not influence at the lymphocytes count in thorax duct lymph, whereas increased count of bone marrow mononuclear cells and bone marrow mesenchymal stem cells compare with CMF treated animal. Also, was found increased proliferation activity of lymphocytes from thorax duct lymph in CMF and exogenous DNA treated groups. Proliferation 
activity of bone marrow mononuclear cells after chemotherapy was decreased, whereas spleenocytes proliferation in CMF and exogenous DNA treated group was increased. The obtained changes in quantity and quality of cells are as a result of toxic effect of chemotherapeutic agents. During chemotherapy often administered leukostimulatory drugs include of drugs on nucleic acids basis, such as ridostin, derinat, polydan [21]. Panagen belongs to drugs that are based on CpGmodified DNA oligonucleotides and often used for induced anticancer immune response [21]. So, multicenter, double-blind, placebo-controlled, phase II clinical trial of Panagen in female patients with stage II-IV breast cancer displayed leukostimulatory and leukoprotective effects during chemotherapy [21].

The development and progression of breast cancer in human are under sex hormones control $[8,10,22]$. In thorax duct lymph of prolactin was decreased in animal after chemotherapy, whereas additional administration exogenous DNA possessed to save it on the levels as in control group of animals. Exogenous DNA also increased of thyroglobulin, whereas decreased of follicle-stimulating hormone compare with CMF treated group. Prolactin and its receptor expressed on human breast epithelium and breast cancer cells [23]. Between thyroperoxidase antibodies, thyroglobulin antibodies and breast cancer were relationships [24]. A retrospective study of the serum hormone levels (follicle-stimulating hormone, luteinizing hormone, progesterone and prolactin) and cancer marker human epidermal growth factor receptor 2 (Her2/neu), and KI-67 in post-menopausal patients with breast cancer revealed that Her-2/neu ${ }^{+}$breast cancer patients exhibited higher serum follicle-stimulating hormone. Also, patients with breast cancer with higher Ki-67 expression displayed higher follicle-stimulating hormone levels in sera [10].

miRNA is a small non-coding RNA regulating gene expression post-transcriptionally, and have tumor-suppressor or oncogenic activity, and are crucial in the initiation and progression of tumors [10-11, 25-27]. We have found that levels of miRNA expression dependence at the subject were it a detected. So, we not found difference in thorax duct lymph for miRNA-21, whereas levels of miRNA-221 and miRNA-222 significantly decreased in experimental group compare with control animal and BC-control. Early we estimated correlations between the levels of miRNA in thorax duct lymph and quantity and quality of hemo- and lymphopoiesis in animals with BC [28]. So, was obtained positive correlation between quantity of spleenocytes and miRNA-21 in animal received polychemotherapy $(\mathrm{r}=0.76, \mathrm{p}=0.027)$. Levels of miRNA-22 1 in thorax duct lymph positively associated with quantity of spleenocytes and quantity of lymphocytes in surgical-treated group of mice with $\mathrm{BC}(\mathrm{r}=0.82, \mathrm{p}=0.041$ and $\mathrm{r}=0.95, \mathrm{p}=0.003$ respectively). Also, lymph miRNA221 positively correlates with TNF- $\alpha$, IL- $1 \beta$ and TGF- $\beta 1$ production by lymphocytes or spleenocytes in surgical-treated group of rat with $\mathrm{BC}(\mathrm{r}=0.95, \mathrm{p}=0.003)$. In $\mathrm{BC}$-group lymph miRNA-22 1 levels correlates with IL- $1 \beta$ production by spleenocytes $(r=0.75, p=0.049)$. Lymph levels of miRNA-222 in BC-group correlates with production of TNF- $\alpha$, IL-1 $\beta$ and TGF- $\beta 1$ by bone marrow mononuclear cells and by spleenocytes $(\mathrm{r}=0.81, \mathrm{p}=0.028)$.

When we detected expression of miRNA in mammary gland tissue was estimated increased expression of miRNA-21 in CMF treated group. Also, in some experimental group was found decreased levels of miRNA-221 expression. Additional administration of exogenous DNA possessed to increased levels of miRNA-21 expression in blood serum. In some group of animal with MNU-induced breast cancer in blood serum were elevated levels of miRNA-221 and miRNA222 expression. Some miRNA correlates with hormone in MNU-induced breast cancer animal. Our result concerning to the expression miRNA are in concordance with results obtained by other researchers, so were found upregulation of miRNA-21 gene in liver, spleen and kidney [26]. It is known that miRNA-221 and miRNA-222 are involved in the promotion of an aggressive basal-like phenotype in breast cancer [29]. Also, was indicated that expression of miRNA-221 or miRNA-222 on luminal like or basal like subtypes of breast cancer cell lines are different and found overexpression of miRNA-221/miRNA-222 in ER-negative breast cancer. It is determined that during neoadjuvant chemotherapy in patients with breast cancer stage II exhibited higher basal miRNAs levels than those with higher stage, especial for miRNA-155 and miRNA-21. During cycle of chemotherapy the miRNAs levels changed, especial in patients with smaller tumor sizes [30]. In 
vitro 5-fluorouracil declined levels of miRNA-221, miRNA-210, miRNA-21 and miRNA-10b in luminal androgen receptor-type triple-negative breast cancer MDA-MB-453 cell line [31].

Cytokines and growth factors mediate not only intercellular communication in the immune system, but also influenced on the other cell types [32-33]. During carcinogenesis observed inflammation, which are important to tumor initiation, promotion, angiogenesis, and metastasis, cytokines are involved in all thesis events [32]. In MNU-induced breast cancer animals we observed increased levels of pro-inflammatory cytokines in blood serum. Surgical excision of mammary gland tissue, chemotherapy, combination surgical treatment with chemotherapy and additional administration of exogenous DNA influence at the cytokines levels in blood serum. It is known that IL-1, IL-6, IL-11, TGF-b stimulate cancer cell proliferation and invasion [32]. Moreover, IL-6 and TNF-alpha can regulate estrogen synthesis in peripheral tissue, including normal and malignant tissues [34].

It is known that intraperitoneal administration of carcinogenetic chemicals induced development of breast cancer with lower metastatic activity [2]. In our breast cancer model was found presence of tumor cells in regional lymph node (axillaries lymph node), and increased count of macrophages not only in axillaries lymph node but also in sternal and mesenteric lymph nodes. Other researchers obtained increased count of mast cells in mammary gland tissue and regional lymph node after subcutaneous administration of MNU in outbred albino rats [35].

\section{Conclusion}

In summary, intermammary administration of MNU may be used as an experimental model of human luminal B type breast cancer to study early stage of carcinogenesis, role of hormones, miRNAs, cytokines in carcinogenesis, and efficiency of chemotherapy.

\section{Conflicts of Interest}

No potential conflict of interest was disclosed.

\section{Acknowledgments}

The Authors thank Ekaterina Lykova for her helping in translation on English.

\section{References}

[1] C. Hui et al., MicroRNA-34 and microRNA-21 play roles in the chemopreventive effects of 3,6-dihydroxyflavone on 1-methyl-1-nitrosourea-induced breast carcinogenesis, Breast Cancer Res. 14 (2012) 80-91.

[2] B. Pula et al., Immunohistochemical Characterization of $N$-Methyl- $N$-Nitrosourea-induced Mammary Tumours of Sprague-Dawley Rats, In vivo. 27 (2013) 793-802.

[3] M. P. Thorpe et al., Breast tumors induced by n-methyl-n-nitrosourea are damaging to bone strength, structure, and mineralization in the absence of metastasis in rats, J. Bone and Mineral Res. 26 (2011) 769-776.

[4] A.D. Papaconstantinou et al., Gene expression profiling in the mammary gland of rats treated with 7,12-dimethylbenz[a]anthracene, Int. J. Cancer. 118 (2006) 17-24.

[5] H. Jaafar, F. Mohmad Irdis, S. N. Mohd Nafi, The association between phenotype and size of breast tumors induced by 1-methyl-1-nitrosourea (MNU) injection in rats, Med. Sci. Monit. 15 (2009) 129-134.

[6] E. El-Abd et al., Histopathological characteristics of breast cancer and evaluation of ER alpha and Her-2neu using immunohistochemical and RT-PCR techniques, Alexandria J. Med. 50 (2014) 275-282. 
[7] S. Bernichtein, P. Touraine, V. Goffin, New concepts in prolactin biology, J. Endocrinol. 206 (2010) 1-11.

[8] G. N. Farhat et al., Sex hormone levels and risks of estrogen receptor-negative and estrogen receptor-positive breast cancers, J. Nat. Cancer Inst. 103 (2011) 562-570.

[9] P. Szychta et al., TSH receptor antibodies have predictive value for breast cancer retrospective analysis, Thyroid Res. 6 (2013) 8-15.

[10] J. Zhou et al., Serum follicle-stimulating hormone level is associated with human epidermal growth factor receptor type 2 and Ki67 expression in post-menopausal females with breast cancer, Oncol Let. 6 (2013) 1128-1132.

[11] P.S. Waters et al., Relationship between circulating and tissue microRNAs in a murine model of breast cancer, PLoS ONE (2012).

[12] M.A. Al-Rakan et al., Breast stromal fibroblasts from histologically normal surgical margins are pro-carcinogenic, J. Pathol. 231 (2013) 457-465.

[13] B.G. Cuiffo et al., MSC-regulated microRNAs converge on the transcription factor FOXP2 and promote breast cancer metastasis, Cell Stem Cell. 15 (2014) 762-774.

[14] C. Zhang et al., Mesenchymal stem cells derived from breast cancer tissue promote the proliferation and migration of the MCF- cell line in vitro, Oncol. Let. 6 (2013) 1577-1582.

[15] A. R. Chochieva, The study of the influence of letrosole on some factors of hormonal and metabolic status under experimental carcinogenesis of the mammary gland, Siberian J. Oncol. 1 (2008) 100-102.

[16] W. Wang et al., Prognostic and predictive value of Ki-67 in triple-negative breast cancer, Information on www.impactjournals.com/oncotarget.

[17] C. Katanov et al., Regulation of the inflammatory profile of stromal cells in human breast

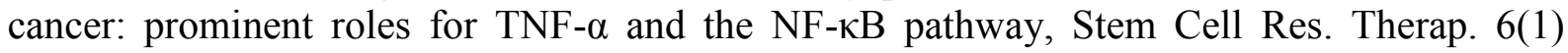
(2015) 87.

[18] L. Lacerda et al., Mesenchymal stem cells mediate the clinical phenotype of inflammatory breast cancer in a preclinical model, Breast Cancer Res. 17 (2015).

[19] L. Usha et al., Mesenchymal stem cells develop tumor tropism but do not accelerate breast cancer tumorigenesis in a somatic mouse breast cancer model, PLoS ONE. 8 (2013).

[20] M. Zhao et al., Mesenchymal stem cells in mammary adipose tissue stimulate progression of breast cancer resembling the basal-type, Cancer Biol. Therapy. 13 (2012) 782-792.

[21] A.S. Proskurina et al., Results of multicenter double-blind placebocontrolled phase II clinical trial of Panagen preparation to evaluate its leukostimulatory activity and formation of the adaptive immune response in patients with stage II-IV breast cancer, BMC Cancer. 15 (2015).

[22] S. Bernichtein, P. Touraine, V. Goffin, New concepts in prolactin biology, J. Endocrinol. 206 (2010) 1-11.

[23] L.M. Nitze et al., Reevaluation of the proposed autocrine proliferative function of prolactin in breast cancer, Breast Cancer Res. Treat. 142 (2013) 31-44.

[24] P. Szychta et al., TSH receptor antibodies have predictive value for breast cancerretrospective analysis, Thyroid Res. 16 (2013).

[25] K.B. Reddy, MicroRNA (miRNA) in cancer, Cancer Cell Intern. 15 (2015).

[26] S.D. Selcuklu et al., Regulatory interplay between miR-21, JAG1 and 17beta-estradiol (E2) in breast cancer cells, Biochem. Biophys. Res. Comm. 423 (2012) 234-239. 
[27] K. Gombos et al., Effect of N-Methyl-N-Nitrosurea on microRNA expression in CBA/CA mice, J. Environ. Occup Sci. 1 (2012) 77-82.

[28] A.P. Lykov et al., The levels of microRNA in the lymph in experimental models of breast cancer, International J. Applied and Fundamental Research. 6 (2015) 445-452.

[29] M.Y. Shah, G.A. Calin, MicroRNAs miR-221 and miR-222: a new level of regulation in aggressive breast cancer, Genome Med. 3(8) (2011) 56.

[30] U. Gezer et al., Abundant circulating microRNAs in breast cancer patients fluctuate considerably during neoadjuvant chemotherapy, Oncol. Let. 8 (2014) 845-848.

[31] Y. Yao et al., 5-FU and ixabepilone modify the microRNA expression profiles in MDA-MB453 triple-negative breast cancer cells, Oncol. Let. 7 (2014) 541-547.

[32] M. Esquivel-Velazquez et al., The role of cytokines in breast cancer development and progression, J. Interferon Cytokine Res. 35 (2015).

[33] A. Nicolini, A. Carpi, G. Rossi, Cytokines in breast cancer, Cytokine Growth Factor Rev. 17 (2006) 325-337.

[34] A. Purohit, S.P. Newman, M.J. Reed, The role of cytokines in regulating estrogen synthesis: implications for the etiology of breast cancer, Breast Cancer Res. 4 (2002) 65-69.

[35] M.E. Dzodzikova et al., Mast cells of the mammary gland and of the regional lymph node in rats with breast cancer induced by N-Methyl-N-Nitrosourea, Morfologiia. 128(4) (2004) 6064. 